\title{
Chemical properties of Technosols in post-mining areas of the Konin-Turek lignite basin in Poland
}

\author{
Krzysztof Otremba, Natalia Tatuśko-Krygier*, Michał Kozłowski \\ Poznań University of Life Sciences, Department of Soil Science and Reclamation, Piątkowska 94, 60-649 Poznań, Poland
}

* DSc. Eng., N. Tatuśko-Krygier, natalia.tatusko@up.poznan.pl, ORCID iD: https://orcid.org/0000-0002-6842-2125

Received: 09.06.2020

Accepted: 07.08.2020

Associated editor: A. Łachacz

\section{Keywords}

Post-mining lignite areas Agricultural reclamation Medicago sativa L Chemical properties of soil Soil organic carbon Technosols

\begin{abstract}
Lignite is still one of the main energy sources in many country. Its opencast exploitation causes a lot of changes in the environment. After mining activities are created new and enduring relief forms such as internal and external dumping ground. The dumps consist of rocks conglomerate lying above the exploited mineral. As a result of reclamation, soil develops of this specific material. The aim of this study was to assess chemical properties of soils developing in post-mining areas of the lignite basin in the Wielkopolska region. The study included analyses of the effect of alfalfa (Medicago sativa L.) grown with orchard grass (Dactylis glomerata L.) on chemical properties of soils in 3 mineral fertilisation variants (0NPK - control, 1NPK and 2NPK). The experiments showed that the analysed soils retained the alkaline reaction, calcium carbonate and available magnesium contents as well as CEC from the parent material. The analyses confirmed a significant effect of both Medicago sativa L. and mineral fertilisation on chemical properties of tested soils. Cultivation of Medicago sativa L. (in the ONPK variant) caused a statistically significant increase in SOC, TN and CEC in the Ap topsoil horizons. Mineral fertilisation additionally enhanced the accumulation of SOC, TN, $\mathrm{P}_{2} \mathrm{O}_{5}$ and $\mathrm{K}_{2} \mathrm{O}$ as well as an increase in CEC value. It needs to be stressed that irrespective of the adopted fertilisation level the investigated soils were characterised by higher SOC, TN, CEC and available $\mathrm{Mg}$ contents compared to means values of these parameters reported in arable mineral soils in Poland.
\end{abstract}

\section{Introduction}

Carbon is the primary energy source in many countries worldwide. In Poland almost $80 \%$ electric energy is generated from coal, of which approx. $1 / 3$ is obtained using lignite (Widera et al., 2016; Euracoal, 2018). The latter raw material is excavated by strip mining, which is the cheapest and simplest technology. However, it leads to several adverse changes in the natural environment. These changes are related with drastic disturbances in the hydrological regime in the area adjacent to the strip mine, elimination of vegetation as well as changes of the relief and landscape of the mining area (Kumar et al., 2015). During the mine's work related to the removal of the rock overburden, transport and deposition of rock material in spoil banks, the original geological structure and soil are completely destroyed (Zhang et al., 2014; Ahirwal and Maiti, 2018). They are replaced with new land, which is typically characterised by nutrient deficits, adverse physical properties (Pająk and Krzaklewski 2007), disturbed water retention capacity as well as reduced microbial population and their activity (Placek-Lapaj et al., 2019). A characteristic feature of post-mining areas, as reported by Liu and Lal (2013), is related to the presence of rocks of varied geologi- cal origin, mineral composition as well as physical and chemical properties. Otremba and Gilewska (2013) stated that in the Konin-Turek Lignite Basin the post-mining areas are a conglomerate of Quaternary boulder loam of the Vistulian and the Warthian glaciation, Quaternary sands, Neogene Poznan clays and sporadically Neogene sands.

In accordance with Polish legal regulations (the Journal of Laws of 1995 no. 16 item 78 with later amendments) such mining lands need to be reclaimed. Selection of an individual reclamation type to a considerable extent depends on physical and chemical properties of this heterogeneous material (Feng et al., 2019). Reconstruction of soil is the primary pre-condition for the development of new ecosystems in post-mining areas. Such locations provide valuable material for studies on the rate and duration of soil formation processes (Abakumov et al., 2013; Frouz et al., 2008). Those authors also reported that both the composition of the parent material and climate have a considerable effect on the intensity of soil formation processes.

Soil development is determined by the amount and quality of organic matter accumulated in the course of the reclamation process (Abakumov et al., 2013). In turn, the amount and quality of organic matter are dependent on the applied reclamation 
treatments, first of all the species of introduced plants and cultivated treatments (Bender, 1995; Pietrzykowski and Krzaklewski, 2010; Gilewska and Otremba, 2018). These factors are also crucial for the development of chemical properties in newly formed soils (Pająk and Krzaklewski, 2006). Assessment of these properties, along with physical and biological properties provides important indications of pedological processes (Mukhopadhyay et al., 2016).

The aim of the study was to assess chemical properties of soils developing under the impact of their agricultural reclamation. This paper presents an analysis of the effect of three mineral fertilisation variants in the cultivation of Medicago sativa $\mathrm{L}$. on accumulation of carbon and major nutrients as well as sorption properties of young soils.

\section{Materials and methods}

\section{Study site}

Investigations were conducted in a post-mining area of the former Pątnów strip lignite mine in the Konin-Turek Lignite Basin near the city of Konin (52^18'41.13”N, 18`15'39.19”E). The experimental field of 20 ha was established in 1978. Results presented in this paper are the effect of agricultural reclamation performed following the concept (PAN model of the Polish Academy of Science) developed by Bender (1995). This study was conducted on 3 experimental sites. In each site a different mineral fertilisation variant was introduced: 0NPK (no fertilisation), 1NPK (160 kg ha-1 year-1 N, $40 \mathrm{~kg} \mathrm{ha}^{-1}$ year $^{-1} \mathrm{P}_{2} \mathrm{O}_{5}, 80 \mathrm{~kg} \mathrm{ha}^{-1}$ year $^{-1} \mathrm{~K}_{2} \mathrm{O}$ ) and 2NPK (320 kg N ha-1 year $^{-1}, 80 \mathrm{~kg} \mathrm{P}_{2} \mathrm{O}_{5}$ ha $^{-1}$ year $^{-1}$, $160 \mathrm{~kg} \mathrm{~K}_{2} \mathrm{O} \mathrm{ha}^{-1}$ year-1 $^{-1}$. Potassium-phosphorus fertilisation was applied in autumn (potassium salt, triple superphosphate or enriched superphosphate), while nitrogen fertilisation was applied in early spring (3rd decade of March - 1st decade of April) in one dose (ammonium nitrate). The cultivated crop was a monoculture of alfalfa (Medicago sativa L.) with a $10 \%$ addition of orchard grass (Dactylis glomerata L.). From the beginning of the experiment these crops were replanted several times. Alfalfa biomass was harvested annually, three or four times a year, with total yields of 15-40 tha $\mathrm{ha}^{-1}$ year $^{-1}$ for the 0NPK variant, 24-60 for 1NPK and 29-85 $\mathrm{t} \mathrm{ha}^{-1}$ year $^{-1}$ green mass in the $2 \mathrm{NPK}$ variant.

\section{Sampling and analyses}

In 2019 in each of the three experimental plots (0NPK, 1NPK and 2NPK) two soil profiles were made to reveal soil morphology. In each case two genetic horizons were distinguished (Ap and C). Each of these horizons was divided into two subhorizons Ap1 and Ap2 as well as C1 and C2. The thickness of the Ap1 subhorizon ranged from 10 to $12 \mathrm{~cm}$, while that of Ap2 ranged from 12.5 to $15.5 \mathrm{~cm}$. Altogether the thickness of both Ap subhorizons ranged from 24 to $26 \mathrm{~cm}$. From each of the distinguished subhorizon soil samples with a disturbed structure were collected. Air dry soil samples were screened using sieves with $2 \mathrm{~mm}$ mesh size diameter. Such prepared samples constituted material for laboratory analyses. The grain size distribution was analysed applying a combination of the hydrometer and the wet-sieve methods (ISO 11277, 2009). The division into texture classes followed the USDA recommendations (Schoeneberger et al., 2012). The sand fraction content ranged from 63 to $70 \%$, the amount of silt within the range of $22-28 \%$, while that of the clay fraction was $8-11 \%$. Irrespective of the soil horizon and fertilisation variant the analysed soils were classified as Spolic Technosols, according to the IUSS Working Group WRB (2015) with texture of fine sandy loam (FLS). The total nitrogen content (TN) in the soil was determined according to Kiejdahl (ISO 11261, 1995). Total carbon content (TC) in the soil was assayed by dry incineration using a Multi N/C 3100 Analytikjena apparatus. Carbonate content $\left(\mathrm{CaCO}_{3}\right)$ was estimated applying Scheibler's volumetric method. Based on TC and carbonate carbon contents the soil organic carbon (SOC) content was calculated from the formula SOC $=\mathrm{TC}-\left(0.12 \times \mathrm{CaCO}_{3}\right)$. The content of available magnesium (Mg) was assayed using the Schachtschabel methods, while available forms of phosphorus $\left(\mathrm{P}_{2} \mathrm{O}_{5}\right)$ and potassium $\left(\mathrm{K}_{2} \mathrm{O}\right)-$ according to Egner-Riehm. Soil $\mathrm{pH}$ was determined using the potentiometric method in $1 \mathrm{~mol} \cdot \mathrm{dm}^{-3} \mathrm{KCl}$ at the soil:solution ratio of 1:2.5 (v:v). Total exchangeable bases (TEB) in soil were assayed using the Mehlich method as modified by Kociałkowski and Ratajczak (1984), while acidity $\left(\mathrm{H}_{\mathrm{exc}}\right)$ was determined in $1 \mathrm{~mol} \mathrm{dm}^{-3} \mathrm{CH}_{3} \mathrm{COONa}$ at $\mathrm{pH}$ 8.2. Their sum constituted total cation exchange capacity (CEC). For each collected soil sample the analyses were performed in 3 replications.

\section{Statistical analysis}

Statistical analyses were performed using the Statistica 13.0 program (StatSoft, Inc., USA) and MS Excel software. Significance of differences in chemical proprieties between the means of the soil subhorizons at individual fertilisation doses, as well as between subhorizons of various fertilisation doses were determined using Tukey's test at $a=0.05$. The differences were considered significant at $\mathrm{p} \leq 0.05$. Correlation coefficients between selected soil properties were calculated using Pearson's test.

\section{Results and discussion}

Analysed soils were characterised by relatively similar reaction. The pH values ranged from 6.94 to 7.69 (Fig. 1). The basic soil reaction was caused by the presence of calcium carbonates (Fig. 2). Calcium carbonates were distributed throughout the entire profile of the analysed soils. Their contents didn't depend on the fertilisation dose and it was varied. The highest calcium carbonate content was found in the Ap1 and C2 subhorizons of the 2NPK variant (59.7 and $60.9 \mathrm{~g} \mathrm{~kg}^{-1}$ ) and the C1 subhorizon in the 0 NPK variant $\left(64.5 \mathrm{~g} \mathrm{~kg}^{-1}\right)$. Significantly lower contents were recorded in the Ap1 and Ap2 subhorizons of the control and $1 \mathrm{NPK}$ variants (from 42.4 to 43.9). The lowest level of carbonates was recorded in the $\mathrm{C} 2$ subhorizon in the $1 \mathrm{NPK}$ variant (40.3 $\mathrm{g} \mathrm{kg}^{-1}$ ) (Fig. 2). Varied amounts of $\mathrm{CaCO}_{3}$ resulted from the specific distribution of the abundant rock in those sites and those less abundant in that compound in the parent material. Calcium carbonate content depends on the 


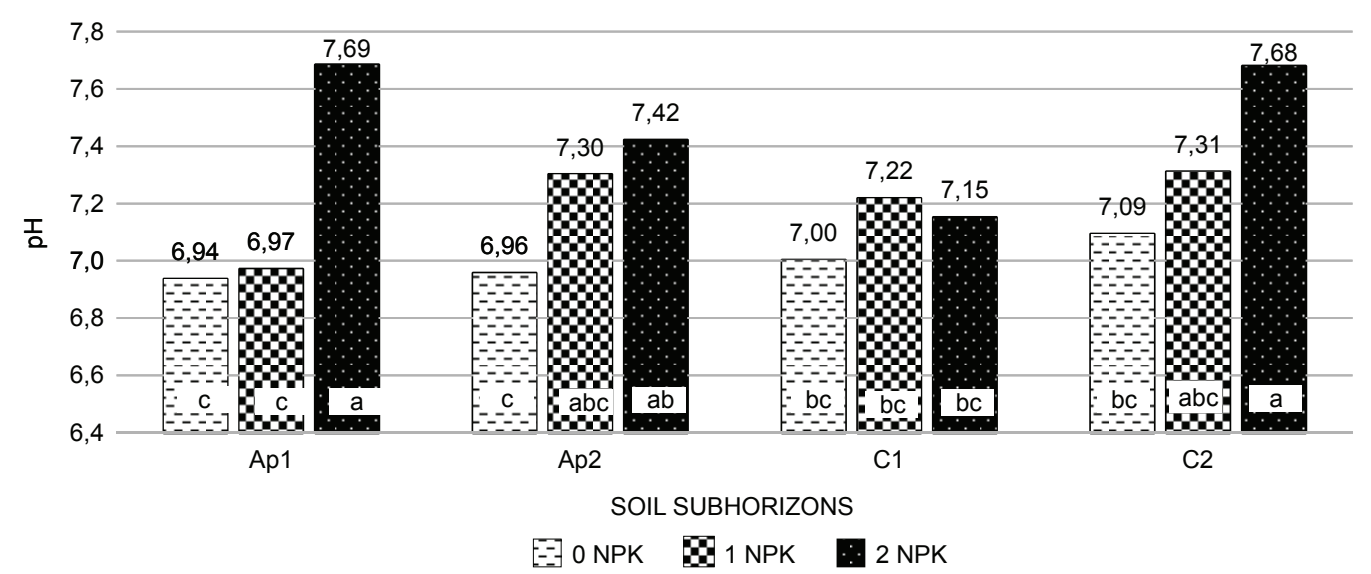

Fig. 1. Mean $\mathrm{pH}$ value in individual soil subhorizons depending on fertilisation variant. Different letters indicate significant differences $(\mathrm{p} \leq 0.05)$ according to Tuckey test

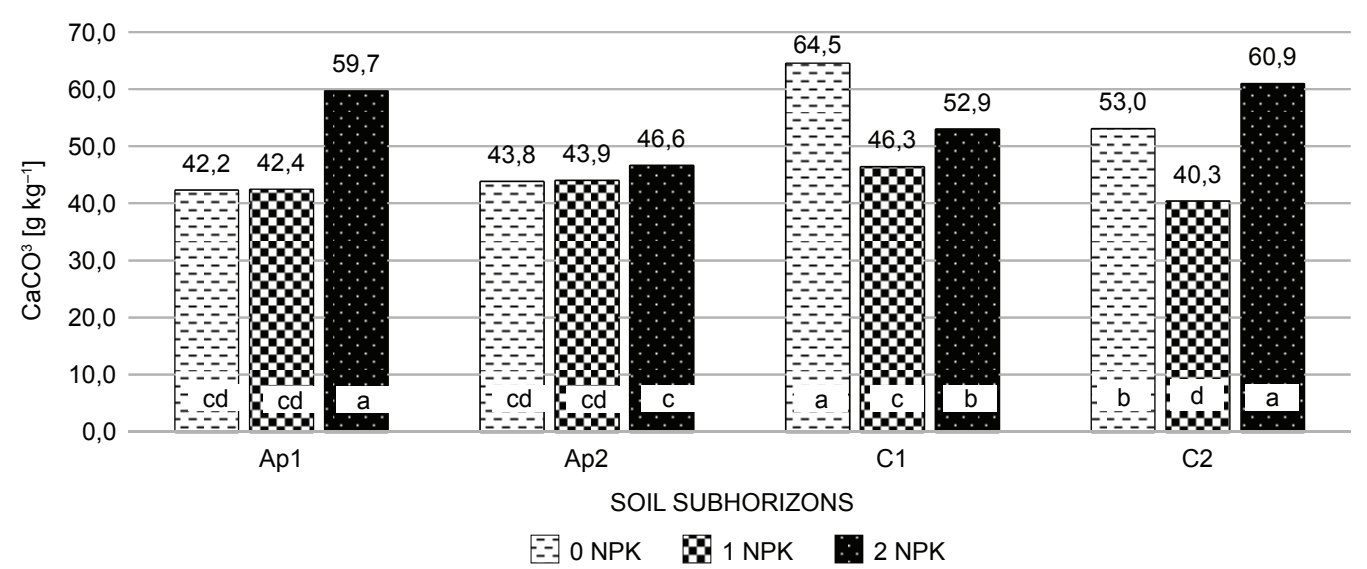

Fig. 2. Mean contents of calcium carbonates in soil subhorizons depending on fertilisation variant. Different letters indicate significant differences $(\mathrm{p} \leq 0.05)$ according to Tuckey test

most variable characteristics of the post-mining area in the Wielkopolska region (Gilewska and Otremba, 2002). The presence of calcium carbonates and the basic soil reaction are also typical of soils developing from that parent material (Gilewska and Otremba $(2004 ; 2018)$. The basic reaction is also reported in German dumps composed of loess (Pihlap et al., 2019).
The level of total carbon (Fig. 3) fell within a wide range of values. In subhorizons Ap1 and Ap2 the TC level was 17.4-21.0 $\mathrm{g} \mathrm{kg}^{-1}$ for 0NPK, 19.3-22.4 $\mathrm{g} \mathrm{kg}^{-1}$ for $1 \mathrm{NPK}$ and 23.8-26.7 $\mathrm{g} \mathrm{kg}^{-1}$ for $2 \mathrm{NPK}$. The TC pool is composed of soil organic carbon (SOC) and inorganic carbon bound with carbonate minerals. As it results from our studies, subhorizons $\mathrm{C} 1$ and $\mathrm{C} 2$ were charac-

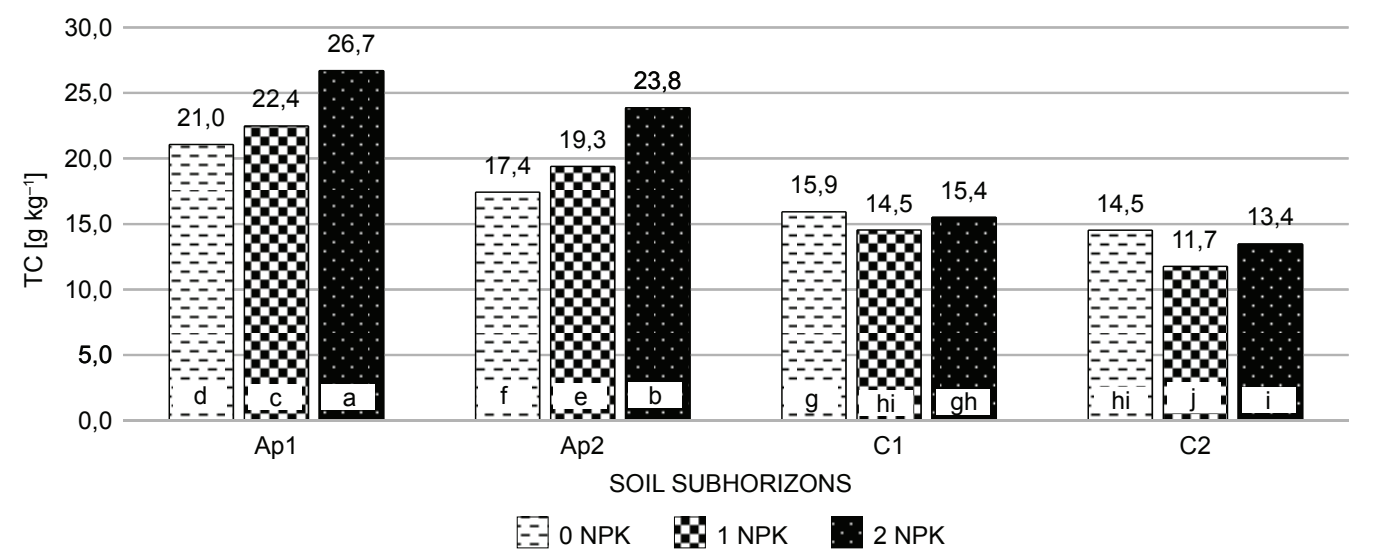

Fig. 3. Mean contents of total carbon in soil subhorizons depending on fertilisation variant. Different letters indicate significant differences $(\mathrm{p} \leq 0.05)$ according to Tuckey test 


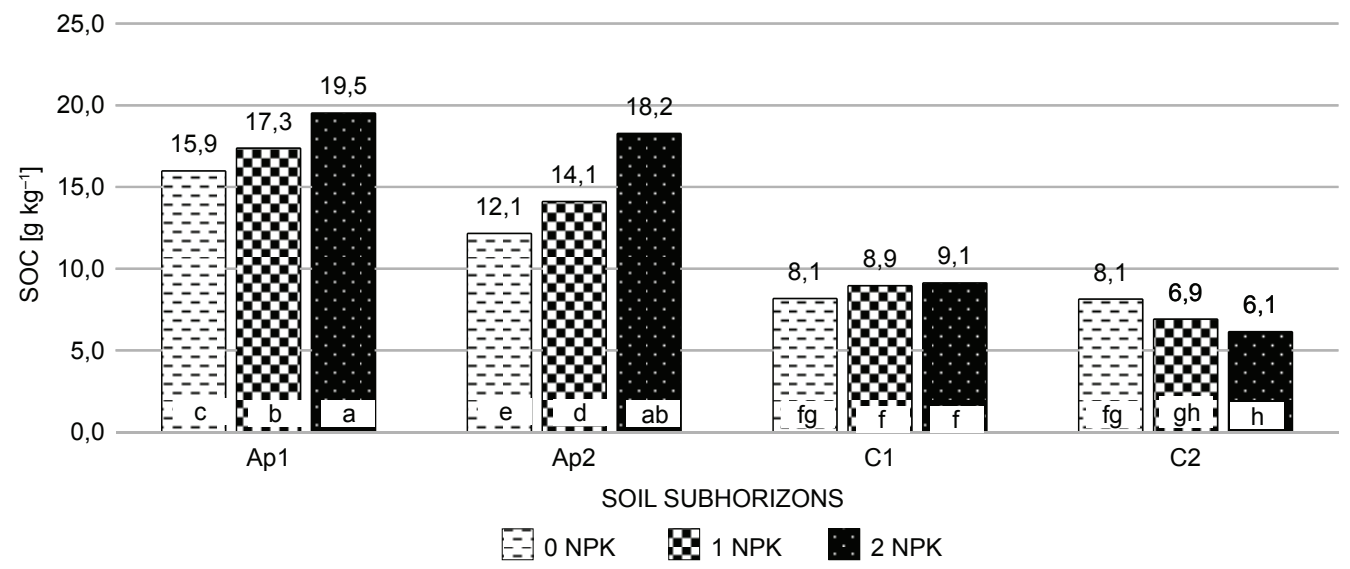

Fig. 4. Mean contents of organic carbon in soil subhorizons depending on fertilisation variant. Different letters indicate significant differences ( $\mathrm{p} \leq 0.05$ ) according to Tuckey test

terised by 1.5 to 2 -fold lower TC content compared to its level in the surface soil horizons. Our results indicate a marked TC accumulation in the Ap horizon. The presence of calcium carbonates in the soil profile increased the TC pool in the analysed soil (Figs. 3 and 4), although no statistically significant correlation of TC with $\mathrm{CaCO}_{3}$ content or $\mathrm{pH}$ was found. The TC content showed the strongest correlation with SOC $(r=0.98)$ (Table 1$)$.
The content of soil organic carbon (SOC) in surface subhorizons Ap1 and Ap2 increased statistically significantly with an increasing fertilisation dose, reaching a maximum in the 2NPK variant (19.5 and $18.2 \mathrm{~g} \mathrm{~kg}^{-1}$ ) (Fig. 4). In the subhorizons of the parent material ( $\mathrm{C} 1$ and $\mathrm{C} 2$ ) the SOC content was considerably less varied and ranged from 6.10 to $9.09 \mathrm{~g} \mathrm{~kg}^{-1}$ (Fig. 4). Thus they were the levels from 2 to 3 -fold lower than in the Ap horizons. It needs to

Table 1

Correlation matrix of chemical properties

\begin{tabular}{|c|c|c|c|c|c|c|c|c|c|c|c|c|c|}
\hline Variable & $\begin{array}{l}\mathrm{TN} \\
{\left[\mathrm{g} \mathrm{kg}^{-1}\right]}\end{array}$ & $\begin{array}{l}\mathrm{TC} \\
{\left[\mathrm{g} \mathrm{kg}^{-1}\right]}\end{array}$ & $\begin{array}{l}\mathrm{SOC} \\
{\left[\mathrm{g} \mathrm{kg}^{-1}\right]}\end{array}$ & $\begin{array}{l}\mathrm{CaCO}_{3} \\
{\left[\mathrm{~g} \mathrm{~kg}^{-1}\right]}\end{array}$ & $\begin{array}{l}\mathrm{P}_{2} \mathrm{O}_{5} \\
{\left[\mathrm{mg} \mathrm{kg}^{-1}\right]}\end{array}$ & $\begin{array}{l}\mathrm{K}_{2} \mathrm{O} \\
{\left[\mathrm{mg} \mathrm{kg}^{-1}\right]}\end{array}$ & $\begin{array}{l}\mathrm{MgO} \\
{\left[\mathrm{mg} \mathrm{kg}^{-1}\right]}\end{array}$ & $\mathrm{pH}$ & $\begin{array}{l}\mathrm{Ca}^{2+} \\
{\left[\mathrm{cmol} \mathrm{kg}^{-1}\right]}\end{array}$ & $\begin{array}{l}\mathrm{K}^{+} \\
{\left[\mathrm{cmol} \mathrm{kg}^{-1}\right]}\end{array}$ & $\begin{array}{l}\mathrm{Na}^{+} \\
{\left[\mathrm{cmol} \mathrm{kg}^{-1}\right]}\end{array}$ & $\begin{array}{l}\mathrm{H}_{\text {exc }} \\
\text { [cmol kg-1] }\end{array}$ & $\begin{array}{l}\text { CEC } \\
{\left[\mathrm{cmol} \mathrm{kg}^{-1}\right]}\end{array}$ \\
\hline $\begin{array}{l}\mathrm{TN} \\
{\left[\mathrm{g} \mathrm{kg}^{-1}\right]}\end{array}$ & 1.00 & $0.95^{*}$ & $0.97^{*}$ & -0.22 & $0.84^{*}$ & $0.87^{*}$ & $0.69^{*}$ & 0.12 & $0.92^{*}$ & $0.52^{*}$ & $0.48^{*}$ & $0.87^{*}$ & $0.93^{*}$ \\
\hline $\begin{array}{l}\mathrm{TC} \\
{\left[\mathrm{g} \mathrm{kg}^{-1}\right]}\end{array}$ & & 1.00 & $0.98^{*}$ & -0.04 & $0.86^{*}$ & $0.90^{*}$ & $0.75^{*}$ & 0.11 & $0.91^{*}$ & $0.55^{*}$ & $0.48^{*}$ & $0.88^{*}$ & $0.92^{*}$ \\
\hline $\begin{array}{l}\mathrm{SOC} \\
{\left[\mathrm{g} \mathrm{kg}^{-1}\right]}\end{array}$ & & & 1.00 & $-0.26^{*}$ & $0.83^{*}$ & $0.85^{*}$ & $0.72^{*}$ & 0.05 & $0.89^{*}$ & $0.58^{*}$ & $0.46^{*}$ & $0.86^{*}$ & $0.90^{*}$ \\
\hline $\begin{array}{l}\mathrm{CaCO}_{3} \\
{\left[\mathrm{~g} \mathrm{~kg}^{-1}\right]} \\
\end{array}$ & & & & 1.00 & 0.04 & 0.12 & 0.02 & $0.27^{*}$ & -0.04 & $-0.26^{*}$ & 0.00 & -0.04 & -0.04 \\
\hline $\begin{array}{l}\mathrm{P}_{2} \mathrm{O}_{5} \\
{\left[\mathrm{mg} \mathrm{kg}^{-1}\right]} \\
\end{array}$ & & & & & 1.00 & $0.91^{*}$ & $0.60^{*}$ & $0.38^{*}$ & $0.79^{*}$ & $0.52^{*}$ & $0.48^{*}$ & $0.73^{*}$ & $0.80^{*}$ \\
\hline $\begin{array}{l}\mathrm{K}_{2} \mathrm{O} \\
{\left[\mathrm{mg} \mathrm{kg}^{-1}\right]}\end{array}$ & & & & & & 1.00 & $0.67^{*}$ & $0.29^{*}$ & $0.86^{*}$ & $0.40^{*}$ & $0.53^{*}$ & $0.79 *$ & $0.86^{*}$ \\
\hline $\begin{array}{l}\mathrm{Mg} \\
{\left[\mathrm{mg} \mathrm{kg}^{-1}\right]}\end{array}$ & & & & & & & 1.00 & -0.06 & $0.72^{*}$ & $0.50^{*}$ & 0.15 & $0.72^{*}$ & $0.72^{*}$ \\
\hline $\mathrm{pH}$ & & & & & & & & 1.00 & 0.13 & -0.21 & $0.38^{*}$ & 0.10 & $0.13^{*}$ \\
\hline $\begin{array}{l}\mathrm{Ca}^{2+} \\
{\left[\mathrm{cmol} \mathrm{kg}^{-1}\right]}\end{array}$ & & & & & & & & & 1.00 & $0.48^{*}$ & $0.46^{*}$ & $0.85^{*}$ & $1.00^{*}$ \\
\hline $\begin{array}{l}\mathrm{K}^{+} \\
{\left[\mathrm{cmol} \mathrm{kg}^{-1}\right]}\end{array}$ & & & & & & & & & & 1.00 & -0.10 & $0.44^{*}$ & $0.50^{*}$ \\
\hline $\begin{array}{l}\mathrm{Na}^{+} \\
{\left[\mathrm{cmol} \mathrm{kg}^{-1}\right]}\end{array}$ & & & & & & & & & & & 1.00 & $0.57^{*}$ & $0.49^{*}$ \\
\hline $\begin{array}{l}\mathrm{H}_{\text {exc }} \\
\text { [cmol kg-1] }\end{array}$ & & & & & & & & & & & & 1.00 & $0.87^{*}$ \\
\hline $\begin{array}{l}\text { CEC } \\
{\left[\mathrm{cmol} \mathrm{kg}^{-1}\right]}\end{array}$ & & & & & & & & & & & & & 1.00 \\
\hline
\end{tabular}

*statistically significant, $\mathrm{p} \leq 0.05$ 
be stressed that in the SOC pool in the post-mining areas not only pedogenic carbon is found, but also geogenic carbon related with the presence of lignite (Greinert et al., 2018). Such a situation was typical of the parent material horizons in the analysed soils. In those horizons not only small lignite crumbs were found, but also reside of thick alfalfa roots. In Ap no lignite particles were observed, which indicates that these horizons contain primarily pedogenic carbon. A significantly greater SOC accumulation in the Ap horizons in the $1 \mathrm{NPK}$ and $2 \mathrm{NPK}$ variants (14.1-19.5 $\mathrm{g} \mathrm{kg}^{-1}$ ) compared to 0NPK (12.1-15.9 $\mathrm{g} \mathrm{kg}^{-1}$ ) was caused, as it may be assumed, by the greater influx of organic compounds, since fertilisation influenced yields of plants, as mentioned above. The yields were greatest for 2NPK and lowest in the case of 0NPK. Greater yields are also connected with greater amounts of plant residue in mining soils. The SOC levels recorded in this study for all the fertilisation variants need to be considered high compared to the mean SOC content in Polish cultivated mineral soils. Siebelec et al. (2017) reported that in 2015 this value was $11.2 \mathrm{~g} \mathrm{~kg}^{-1}$.

Presented results are characteristic of processes observed in the initial stages of soil formation. Reintam et al. (2002), Fettweis et al. (2005) and Pihlap et al. (2019) indicated that the accumulation and humification of organic matter play the main role in the initial soil formation stages. The soil organic matter (humus) serves a key role in the modification of soil properties not only in reclaimed areas (Vindušková and Frouz, 2013; Zhao et al., 2013; Bao et al., 2017; Ahirwal et al., 2018), but also in arable soils (Chaudhari et al., 2013; Scotti et al., 2015). Humus is a significant link in the cycle of mineral nutrition of plants and soil organisms by storing and enhancing the availability of nutrients, mainly nitrogen and phosphorus (Stevenson, 1994; Frouz et al., 2008; Pietrzykowski, 2010). Presented results indicate that despite the passage of over 40 years since the initiation of soil formation, the analysed Technosols still show a clear carbon sequestration. This process has also been highlighted by Ahirwal et al. (2018) and Mukhopadhyay et al. (2016). Our results indicate that SOC is positively correlated with all determined properties (except for $\mathrm{pH}$ and $\mathrm{CaCO}_{3}$ ). Values of the correlation coefficient for SOC with TN need to be stressed in this respect $(\mathrm{r}=0.97), \mathrm{CEC}$ $(\mathrm{r}=0.90), \mathrm{Ca}^{2+}(\mathrm{r}=0.89), \mathrm{K}_{2} \mathrm{O}(\mathrm{r}=0.85) \mathrm{P}_{2} \mathrm{O}_{5}(\mathrm{r}=0.83)$ (Table 1$)$.
Nitrogen is a macronutrient, which determines not only the amount of biomass produced in the course of the reclamation processes, but also the rate of soil formation processes and indirectly also soil structure formation processes (Bender, 1995; Gilewska, 2000). In post-mining areas a deficit of this macronutrient is observed. For this reason in various reclamation technologies, irrespective of the adopted direction, nitrogen supply is focused on. It is provided by mineral fertilisation or introduction of legumes or other plants capable of fixing atmospheric nitrogen thanks to symbiosis with rhizosphere microorganisms (Fustec et al., 2010; Chodak et al., 2019; Pihlap et al., 2019). As it results from our study (Fig. 5), the TN levels in subhorizons Ap1 and Ap2 were statistically significantly greater than in the other analysed subhorizons. In the case of each fertilisation variant the Ap1 subhorizon was always characterised by significantly greater TN contents than Ap2. The fertilisation variant also had a significant effect on TN content. With an increased fertilisation dose the content of nitrogen in soils increased reaching a peak in subhorizon Ap1 in the 2NPK variant ( $\left.3.17 \mathrm{~g} \mathrm{~kg}^{-1}\right)$. It needs to be stressed that TN content in the $1 \mathrm{NPK}$ and $2 \mathrm{NPK}$ variants is a consequence of a joint effect of mineral fertilisation and nitrogen fixation by Medicago sativa L. In turn, in the 0 NPK variant (1.83-2.06 $\mathrm{g} \mathrm{kg}^{-1}$ ) the TN content results only from the effect of alfalfa (Medicago sativa L.). The 3- to 4-fold lower TN contents were found in the subhorizons of the parent material ( $\mathrm{C} 1$ and C2), which indicates a marked accumulation of this macronutrient in the topsoil. The amount of TN in soil subhorizons Ap in all fertilisation variants fell within the upper limit of values given by Siebielec et. al. (2017) for arable soils in Poland (0.4-3.6 $\left.\mathrm{g} \mathrm{kg}^{-1}\right)$. In relation to the mean values in arable soils $\left(1.12 \mathrm{~g} \mathrm{~kg}^{-1}\right)$ reported by the above-mentioned authors, the amount of TN in the Ap soil horizon in the control variant was almost 2-fold and in the 2 NPK variant was as much as 3-fold greater.

It results from the data given in Table 1 that the amount of TN, similarly as SOC, is positively correlated with all the determined properties except for $\mathrm{pH}$ and $\mathrm{CaCO}_{3}$. Accumulation of $\mathrm{TN}$ resulted not only in the increased levels of total nitrogen, but also reduction of the SOC:TN ratio (Fig. 6). In subhorizons Ap1 and Ap2 this ratio ranged from 6.14 to 7.7. Such a narrow value

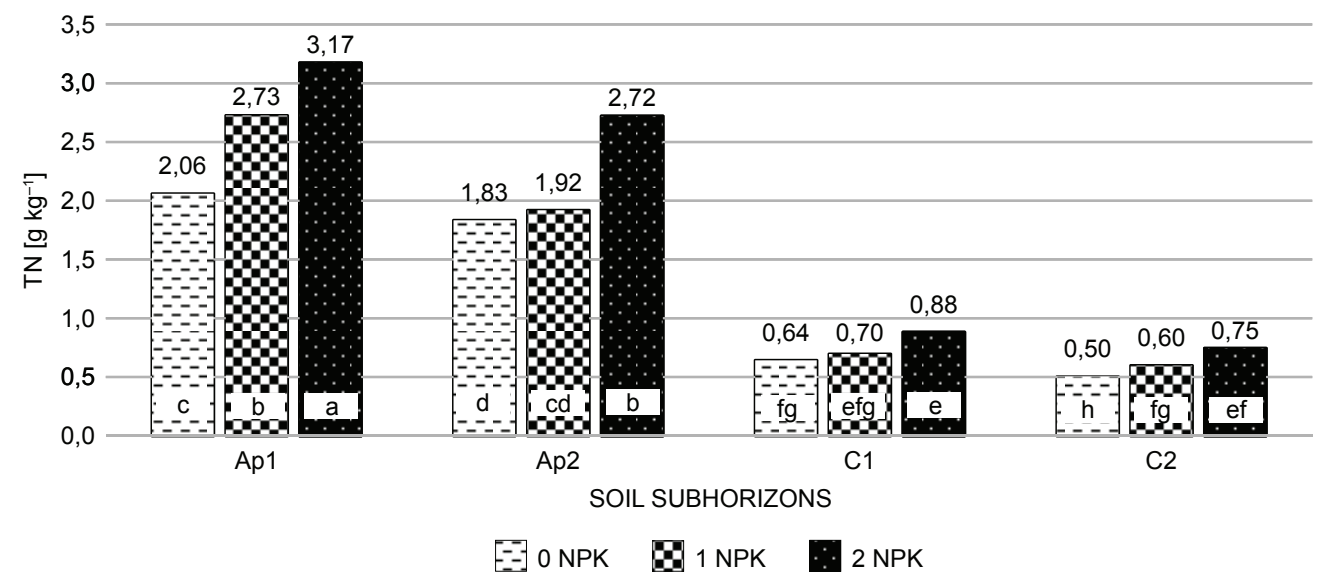

Fig. 5. Mean contents of total nitrogen in soil subhorizons depending on fertilisation variant. Different letters indicate significant differences ( $\mathrm{p} \leq 0.05)$ according to Tuckey test 
of the SOC:TN ratio indicates a rapid rate of transformation of organic matter introduced to the formed soil. In the parent material horizons the SOC:TN ratio fell with a wider range of values from 8.2 to 16.1. The smallest range of the SOC:TN ratio in the parent material horizons was recorded in the 2NPK fertilisation variant, in which every year $320 \mathrm{~kg} \mathrm{~N} \mathrm{~kg} \mathrm{ha-1}$ were introduced, while it was widest for 0NPK. Nitrogen fertilisation in alfalfa growing may have limited the development of Rhizobium and Bradyrhizobium bacteria, and thus reduced the capacity to fix molecular nitrogen. The inhibitory effect of mineral nitrogen consists in the limitation of development of root nodule biomass and a reduction of nitrogenase enzymatic activity (Gaweł, 2011). In view of the above at the current stage of the research it seems that nitrogen fertilisation in alfalfa cultivation in post-mining areas may not be required.

Apart from nitrogen another deficient macronutrient in post-mining areas is phosphorus (Pietrzykowski and Krzaklewski, 2010; Zoubková et al., 2015). Previous studies (Gilewska, 2000; Gilewska and Otremba, 2004) indicated a rapid accumulation of available phosphorus forms in soils developing in postmining areas. This is also confirmed by the present study (Fig. 7). The greatest contents of available phosphorus forms were found in the topsoil subhorizons: Ap1 (206.9 $\mathrm{mg} \mathrm{kg}^{-1}$ ) and Ap2
(124.4 mg kg-1) in the 2NPK variant. Contents over $201 \mathrm{mg} \mathrm{kg}^{-1}$ $\mathrm{P}_{2} \mathrm{O}_{5}$ in arable soils are considered very high. The amount of this macronutrient in the topsoil horizons decreased significantly as follows: $2 \mathrm{NPK}>1 \mathrm{NPK}>0 \mathrm{NPK}$. In the $1 \mathrm{NPK}$ variant the content of $\mathrm{P}_{2} \mathrm{O}_{5}$ was between low and medium. In subhorizon Ap1 - 0NPK a low value was recorded, but it was a statistically significant and greater (almost 2-fold) content of phosphorus than in the deeper soil subhorizons. This indicates a slow process of accumulation of this element under the influence of cultivated crops (Medicago sativa L.). The alfalfa plant mass, as reported by Gawel (2011), is abundant in nutrients, among other phosphorus. It may be assumed that biomass entering the soil and undergoing decomposition processes results an enrichment of subhorizon Ap1 with this macronutrient. These studies showed no statistically significant correlation for contents of available phosphorus forms only with $\mathrm{CaCO}_{3}$ contents. In contrast, statistically significant correlations were observed with all the other parameters. Compared to the mean content of available phosphorus forms in Polish mineral soils (154 $\mathrm{mg} \mathrm{kg}^{-1}$ ) reported by Siebielec et. al. (2017) in the Ap horizon in the 0NPK variant the levels of this macronutrient are approx. 3-fold lower, in the $1 \mathrm{NPK}$ variant 2 -fold, while in the $2 \mathrm{NPK}$ variant they exceed the mean.

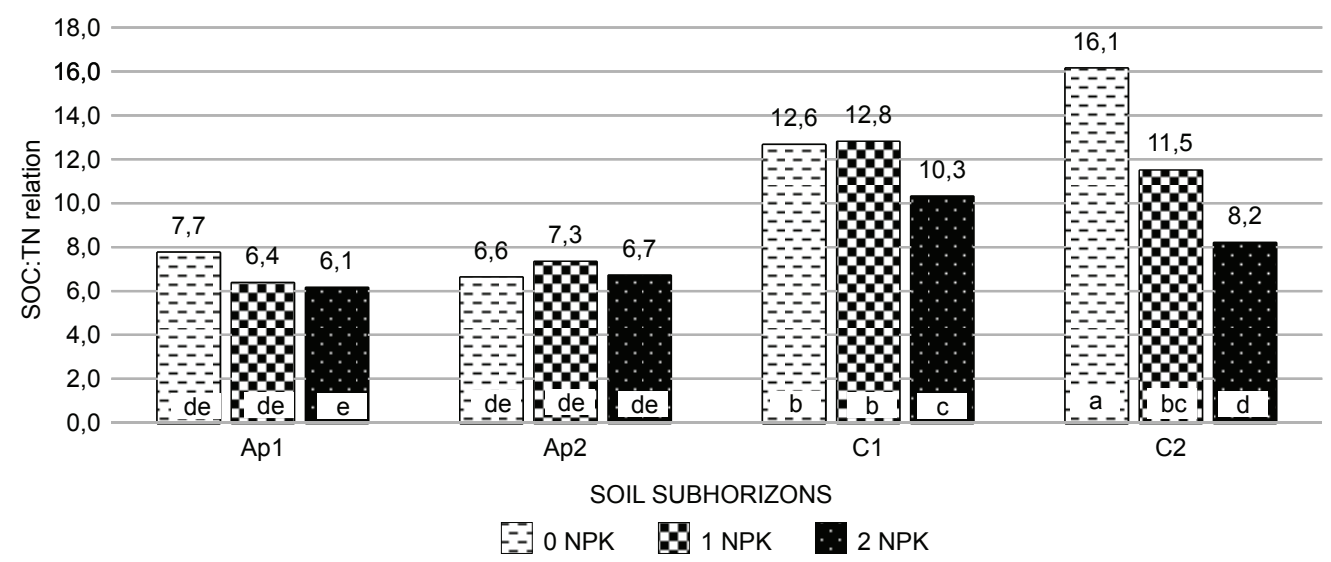

Fig. 6. The SOC:TN ratio in soil subhorizons depending on fertilisation variants. Different letters indicate significant differences $(p \leq 0.05)$ according to Tuckey test

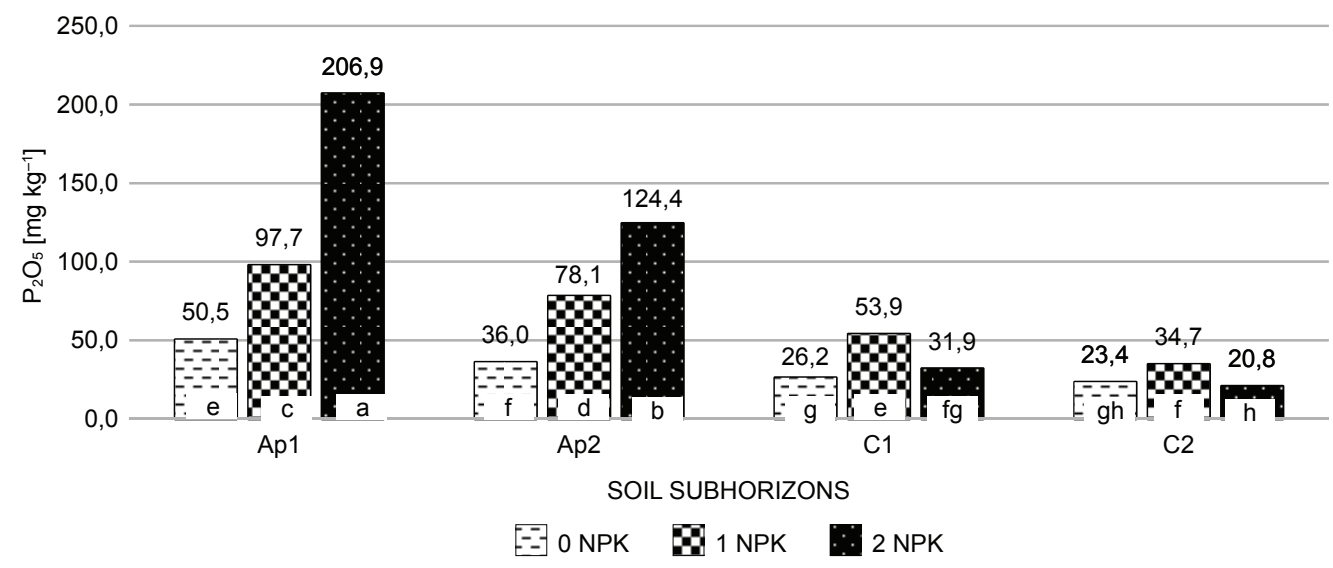

Fig. 7. Mean contents of available phosphorus forms in soil subhorizons depending on fertilisation variant. Different letters indicate significant differences $(\mathrm{p} \leq 0.05)$ according to Tuckey test 
Moreover, significant differences were also observed in contents of available potassium (Fig. 8) both between the soil horizons and in the fertilisation variants. Content of this macronutrient was very low in subhorizons Ap1 and Ap2 in the 0NPK variant as well as $\mathrm{C} 1$ and $\mathrm{C} 2$ for all the fertilisation variants, whereas it was medium in the Ap horizon at 2NPK. It needs to be added here that despite marked differences in contents of available potassium forms in the analysed soils they were even lower than the mean in arable soils (Siebielec et. al., 2017). Content of potassium in the soils investigated in our study may be partly modified by its presence in minerals such as smectite and illite. Presence of these minerals was confirmed by earlier studies (Otremba and Gilewska, 2013). A very strong positive correlation of $\mathrm{P}_{2} \mathrm{O}_{5}$ and $\mathrm{K}_{2} \mathrm{O}$ contents needs to be stressed here $(\mathrm{r}=0.91)$, as it indicates that both macronutrients are strongly dependent on the applied mineral fertilisation variant (Table 1).

Data presented in Fig. 9 concerning contents of available magnesium show considerable abundance of soils formed in post-mining areas in terms of content of this macronutrient. As it results from the study, the greatest content of available $\mathrm{Mg}$ forms was recorded for subhorizon Ap1, particularly in the 0NPK and 2NPK variants ( $81.7 \mathrm{mg} \mathrm{kg}^{-1}$ and $88.0 \mathrm{mg} \mathrm{kg}^{-1}$, respectively). We also need to stress high contents of available $\mathrm{Mg}$ also in the other soil subhorizons (from 50.3 to $72.8 \mathrm{mg} \mathrm{kg}^{-1}$ ) compared to arable soils in Poland (1-32 $\mathrm{mg} \mathrm{kg}^{-1}$ ) (Siebielec et. al., 2017). Such results indicate that the amount of magnesium in the soil developing in post-mining areas is determined first of all by its content in overburden rocks, i.e. it is of geogenic origin. Zoubková et al. (2015) and Frouz et al. (2011) pointed to high contents of magnesium in Czech post-mining areas composed of Miocene clays.

The CEC values in the analysed soils ranged from 7.45 to $13.16 \mathrm{cmol} \mathrm{kg}^{-1}$. These are values exceeding the mean cation exchange capacity $\left(6.51 \mathrm{cmol} \mathrm{kg}^{-1}\right.$ ) of arable soils in Poland (Siebielec et. al., 2017). The highest cation exchange capacity was found for topsoil subhorizons Ap1 and Ap2 (10.14-13.16 cmol $\mathrm{kg}^{-1}$ ). It needs to be stressed here that these values increased significantly with an increase in the fertilisation dose. This was probably caused by the increasing SOC. An increase in SOC resulted in an greater amount of organic colloids and these in turn contributed to an increased CEC in soil. Compared to the Ap horizon the CEC values in subhorizons $\mathrm{C} 1$ and $\mathrm{C} 2$ were by $2-4 \mathrm{cmol} \cdot \mathrm{kg}^{-1}$ lower. The high CEC value in these subhorizons resulted first of all from the presence of illite and smectite in the colloid clay fraction of the analysed soils, as reported by Otremba and Gilewska (2013) (Fig. 10A). Additionally, the presence of iron and aluminium oxides may not be excluded here. The

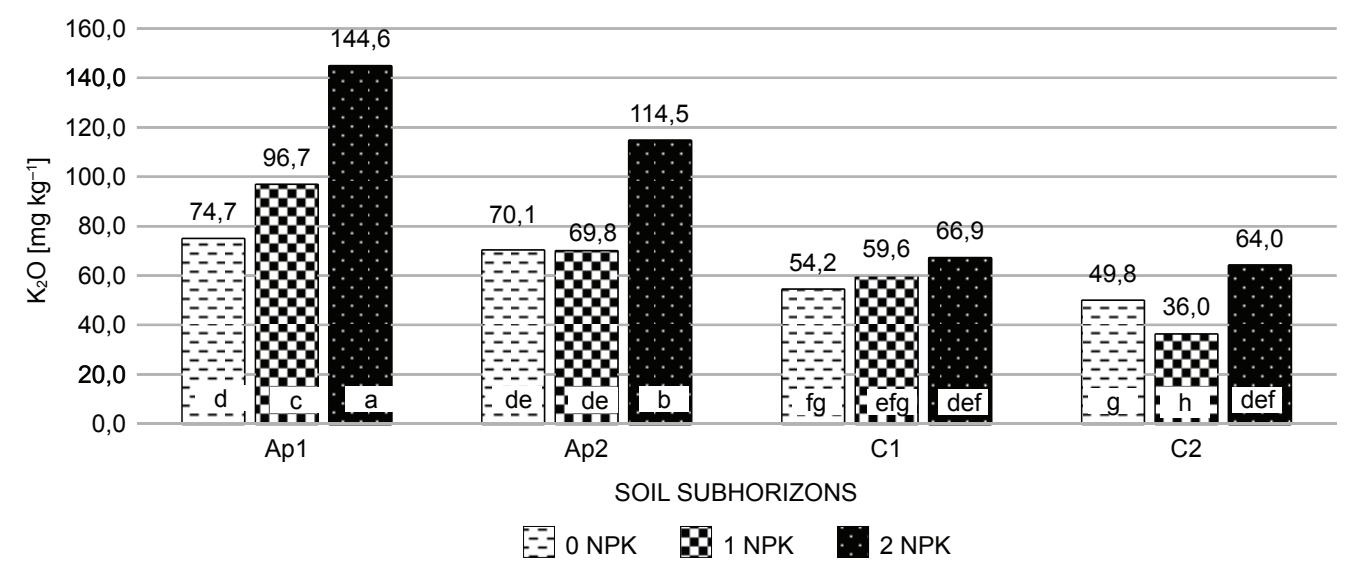

Fig. 8. Mean contents of available potassium forms in soil subhorizons depending on fertilisation variant. Different letters indicate significant differences $(\mathrm{p} \leq 0.05)$ according to Tuckey test

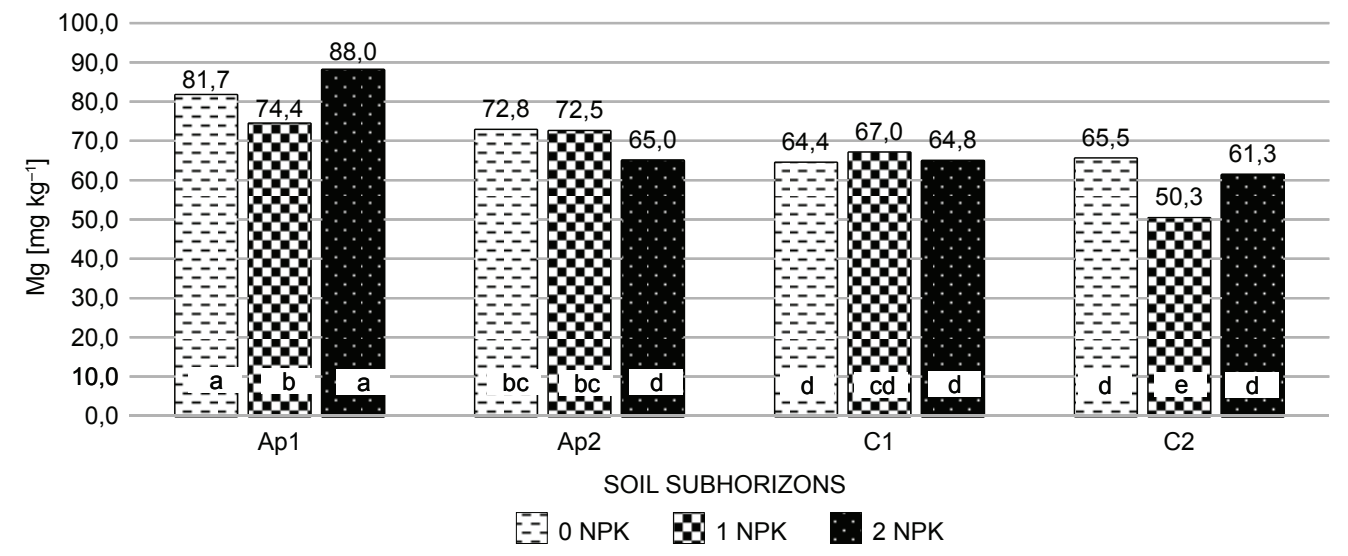

Fig. 9. Mean contents of available magnesium forms in soil subhorizons depending on fertilisation variant. Different letters indicate significant differences $(\mathrm{p} \leq 0.05)$ according to Tuckey test 
considerable effect of the above-mentioned properties on CEC in arable soils was reported by (Asadu et al., 1997; Morrás, 1995; Soares et al., 2005). Those authors added that a marked role in the modification of CEC in soil is played by the origin and properties of the parent rock (its mineral composition, susceptibility to weathering), pedogenic processes and climatic conditions (affecting the intensity of weathering processes). Moreover, it also results from our analyses that the $\mathrm{Ca}^{+2}$ cation accounted for $83 \%$ cation exchange capacity. The share of calcium in CEC, as shown in Fig. 10B, particularly in subhorizon Ap1 increased from 85\% in the soil of the 0NPK variant to $87.2 \%$ in $2 \mathrm{NPK}$. This may have been caused by partial extraction of calcium from carbonates during assays of basic cations (Brogowski and Chojnicki, 2019). Those authors extensively described the role of calcium in the modification of CEC in arable soils developing from glacial tills. As it was reported by those authors, the formation of active carbonates is a major process in chemical weathering. The varied influx of organic matter to the Ap horizons, a greater pool of hydrogen ions as well as variable moisture conditions may facilitate the formation of active carbonates, from which $\mathrm{Ca}$ is the most readily leached element. Obtained results and the high correlation coefficient between $\mathrm{Ca}^{+2}$ and $\mathrm{H}_{\text {exc }}(\mathrm{r}=0.85)$ may indicate that the level of fertilisation through the amount of organic matter reaching the soil influences the intensity of weathering processes (Table 1).

The amount of potassium in CEC decreases with increasing fertilisation doses. This may be associated with the reversal process of this macronutrient. This process under conditions found in soils developing in post-mining areas in the Wielkopolska region was reported by Gilewska (2000). The shares of individual components in CEC decreased in the following order $\mathrm{Ca}^{+2} \rightarrow \mathrm{Mg}^{+2} \rightarrow \mathrm{H}^{+}=\mathrm{K}^{+} \rightarrow \mathrm{Na}^{+}$(Fig. 10B).

\section{Conclusions}

The obtained results indicate that irrespective of the applied fertilisation variant cultivation of Medicago sativa L. had a significant effect on changes in the chemical properties of soils developing in the Pątnów spoil bank in the Konin-Turek Ligite

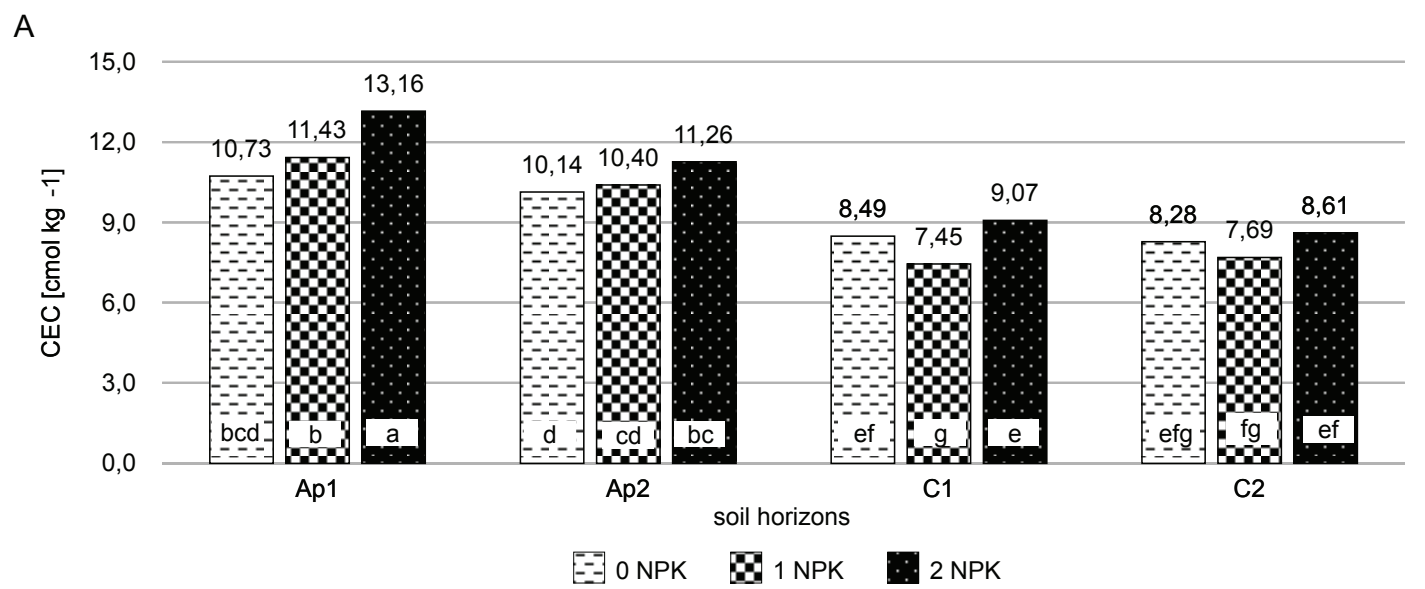

B

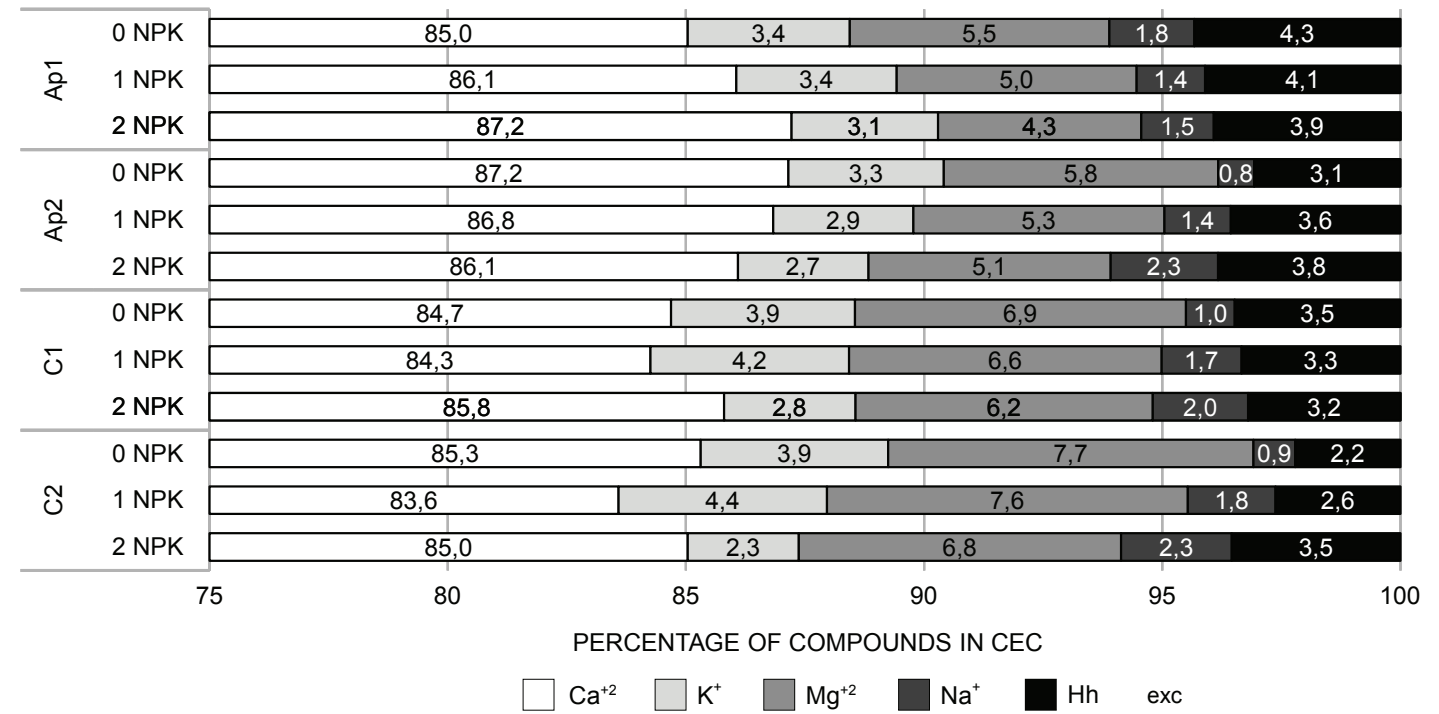

Fig. 10. Cation exchange capacity in reclaimed soil: A - mean of CEC in soil subhorizons depending on fertilisation variant, B - percentage shares of individual CEC components depending on soil subhorizon and fertilisation variant. Different letters indicate significant differences ( $p \leq 0.05$ ) according to Tuckey test 
Basin. The observed effects were manifested in the statistically significant increase in SOC and TN contents as well as CEC in topsoil subhorizons Ap1 and Ap2 in the 0NPK variant (no mineral fertilisation). Mineral fertilisation (1NPK and 2NPK) additionally intensified changes in these chemical properties, while it also caused an accumulation of contents of available phosphorus and potassium forms.

The results indicate that mineral fertilisation probably stimulates also $\mathrm{Ca}^{+2}$ leaching from carbonates. However, it may be assumed to be an indirect effect through the increased penetration of organic matter to the soil.

Among the recorded properties, the analysed soils retain the following features from the parent material: the basic reaction, the presence of calcium carbonates, high contents of available magnesium and relatively high CEC value.

The recorded high TN content and a narrow range of the SOC:TN ratio in the case of all the fertilisation variants indicate the potential elimination of nitrogen fertilisation in alfalfa culture in post-mining areas. This is because it may reduce fixing of atmospheric nitrogen by Medicago sativa $\mathrm{L}$.

\section{Acknowledgments}

The research carried out thanks to the funding of the Ministry of Science and Higher Education from funds for statutory activity and Marshal's Office of the Wielkopolska Region.

\section{References}

Abakumov, E.V., Cajthaml, T., Brus, J., Frouz, J., 2013. Humus accumulation, humification, and humic acid composition in soils of two postmining chronosequences after coal mining. Journal of Soils and Sediments 13(3), 491-500. https://doi.org/10.1007/s11368-012-0579-9

Act on the protection of arable and forest lands (The Journal of Laws of 1995 no. 16 item 78 with later amendments).

Ahirwal, J., Maiti, S.K., 2018. Development of Technosol properties and recovery of carbon stock after 16 years of revegetation on coal mine degraded lands, India. Catena 166, 114-123. https://doi.org/10.1016/ j.catena.2018.03.026

Ahirwal, J., Kumar, A., Pietrzykowski, M., Maiti, S.K., 2018. Reclamation of coal mine spoil and its effect on Technosol quality and carbon sequestration: a case study from India. Environmental Science and Pollution Research 25(28), 27992-28003. https://doi.org/10.1007/s11356018-2789-1

Asadu, C.L.A., Diels, J., Vanlauwe, B., 1997. A comparison of the contributions of clay, silt, and organic matter to the effective CEC of soils of subsaharan Africa. Soil Science 162(11), 785-794.

Bao, N., Wu, L., Ye, B., Yang, K., Zhou, W., 2017. Assessing soil organic matter of reclaimed soil from a large surface coal mine using a field spectroradiometer in laboratory. Geoderma 288, 47-55. https://doi. org/10.1016/j.geoderma.2016.10.033

Bender, J., 1995. Reclamation in post mining area in Poland. Advances of Agricultural Sciences Problem 418, 76-85. (in Polish)

Brogowski, Z., Chojnicki, J., 2019. Sorption properties of granulometric fractions in Haplic Cambisol developed from boulder loam. Soil Science Annual 70(2), 147-157. https://doi.org/10.2478/ssa-2019-0013

Chaudhari, P.R., Ahire, D.V., Ahire, V.D., Chkravarty, M., Maity, S., 2013. Soil bulk density as related to soil texture, organic matter content and available total nutrients of Coimbatore soil. International Journal of Scientific and Research Publications 3(2), 1-8.
Chodak, M., Sroka, K., Woś, B., Pietrzykowski, M., 2019. Effect of green alder (Alnus viridis) and black alder (Alnus glutinosa) on chemical and microbial properties of sandy mine soils. Geoderma 356, 113924. https://doi.org/10.1016/j.geoderma.2019.113924

Euracoal., 2018. Country profiles: Poland. https://euracoal.eu/info/country-profiles/poland/. Accessed 5 May 2019

Fettweis, U., Bens, O., Hüttl, R.F., 2005. Accumulation and properties of soil organic carbon at reclaimed sites in the Lusatian lignite mining district afforested with Pinus sp. Geoderma 129(1-2), 81-91. https:// doi.org/10.1016/j.geoderma.2004.12.034

Feng, Y., Wang, J., Bai, Z., Reading, L., 2019. Effects of surface coal mining and land reclamation on soil properties: A review. Earth-science Reviews 191, 12-25. https://doi.org/10.1016/j.earscirev.2019.02.015

Frouz, J., Prach, K., Pižl, V., Háněl, L., Starý, J., Tajovský, K., Materna, J., Balík, V., Kalčík, J., Řehounková, K., 2008. Interactions between soil development, vegetation and soil fauna during spontaneous succession in post mining sites. European Journal of Soil Biology 44(1), 109-121. https://doi.org/10.1016/j.ejsobi.2007.09.002

Frouz, J., Kalčík, J., Velichová, V., 2011. Factors causing spatial heterogeneity in soil properties, plant cover, and soil fauna in a non-reclaimed post-mining site. Ecological Engineering 37(11), 1910-1913. https:// doi.org/10.1016/j.ecoleng.2011.06.039

Fustec, J., Lesuffleur, F., Mahieu, S., Cliquet, J.B., 2010. Nitrogen rhizodeposition of legumes. A review. Agronomy for Sustainable Development 30(1), 57-66. https://doi.org/10.1051/agro/2009003

Gaweł, E., 2011. The role of fine-grained legume plants in a farm. WaterEnvironment-Rural Areas 11, 73-91. (in Polish)

Gilewska, M., 2000. The role of macroelements in reclamation of dump soil. Roczniki Akademii Rolniczej w Poznaniu, Rolnictwo (56), 391-400. (in Polish)

Gilewska, M., Otremba, K., 2004. Properties of soils formed from postmining soil. Soil Science Annual 55(2), 111-121. (in Polish)

Gilewska, M., Otremba, K., 2002. Spatial variability of some properties on dump soil. Roczniki Akademii Rolniczej w Poznaniu. Melioracje i Inżynieria Środowiska (23), 83-93. (in Polish)

Gilewska, M., Otremba, K., 2018. The some aspects of agricultural reclamation the post-mining grounds of the Konin and Adamów Brown Coal Mines. Ecological Engineering 19(4), 22-29. (in Polish) https:// doi.org/10.12912/23920629/93486

Greinert, A., Drab, M., Śliwińska, A., 2018. Storage capacity of organic carbon in the reclaimed post-mining technosols. Environment Protection Engineering 44(1), 117-127. http://dx.doi.org/ 10.5277\%2Fepe180109

IUSS Working Group WRB., 2015. World Reference Base for Soil Resources 2014, Update 2015: International Soil Classification System for Naming Soils and Creating Legends for Soil Maps. World Soil Resources Reports; FAO: Rome, Italy; No. 106.

ISO 11261, 1995: Determination of Total Nitrogen - Modified Kjeldahl Method.

ISO 11277, 2009: Determination of Particle Size Distribution in Mineral Soil Material - Method by Sieving and Sedimentation

Kociałkowski, W.Z., Ratajczak, M.J., 1984. Simplified Mehlich’s method for the determination of soil cation exchange capacity. Annual of Agriculture University of Poznań 146, 105-116 (in Polish).

Kumar, S., Maiti, S.K., Chaudhuri, S., 2015. Soil development in 2-21 years old coalmine reclaimed spoil with trees: A case study from SonepurBazari opencast project, Raniganj Coalfield, India. Ecological Engineering 84, 311-324. https://doi.org/10.1016/j.ecoleng.2015.09.043

Liu, R., Lal, R., 2013. A laboratory study on amending mine soil quality. Water, Air \& Soil Pollution 224(9), 1679. https://doi.org/10.1007/ s11270-013-1679-x

Morrás, H.J., 1995. Mineralogy and cation exchange capacity of the fine silt fraction in two soils from the southern Chaco Region (Argentina). Geoderma 64(3-4), 281-295. https://doi.org/10.1016/00167061(94)00024-5 
Mukhopadhyay, S., Masto, R.E., Cerdŕ, A., Ram, L.C., 2016. Rhizosphere soil indicators for carbon sequestration in a reclaimed coal mine spoil. Catena 141, 100-108. https://doi.org/10.1016/j.catena.2016.02.023

Otremba, K., Gilewska, M., 2013. Mineralogical composition of post-mining grounds of soils developing from this parent material. Scientific Papers of the Zielona Góra University of Technology, Environmental Engineering 150(30), 34-42 (in Polish)

Pająk, M., Krzaklewski, W., 2006. Selected chemical properties of initial soils on the outside spoilbank of the "Bełchatów" mine. Soil Science Annual LVII("), 158-163 (in Polish).

Pająk, M., Krzaklewski, W., 2007. Selected physical properties of initial soils on the outside spoil bank of the Bełchatów brown coal mine. Journal of Forest Science 53(7), 308-313. https://doi.org/10.17221/2077-JFS

Pietrzykowski, M., 2010. Scots pine (Pinus sylvestris L.) ecosystem macronutrients budget on reclaimed mine sites-stand trees supply and stability. Natural Science 2(06), 590. http://dx.doi.org/10.4236/ ns.2010.26074

Pietrzykowski, M., Krzaklewski, W., 2010. Potential for carbon sequestration in reclaimed mine soil on reforested surface mining areas in Poland. Natural Science 2(09), 1015. http://dx.doi.org/10.4236/ ns.2010.29124

Pihlap, E., Vuko, M., Lucas, M., Steffens, M., Schloter, M., Veettrlein, D., Endenich, M., Kögel-Knabner, I., 2019. Initial soil formation in an agriculturally reclaimed open-cast mining area - the role of management and loess parent material. Soil and Tillage Research 191, 224-237. https://doi.org/10.1016/j.still.2019.03.023

Placek-Lapaj, A., Grobelak, A., Fijalkowski, K., Singh, B.R., Almås, Å.R., Kacprzak, M., 2019. Post-mining soil as carbon storehouse under Polish conditions. Journal of Environmental Management 238, 307-314. https://doi.org/10.1016/j.jenvman.2019.03.005

Reintam, L., Kaar, E., Rooma, I., 2002. Development of soil organic matter under pine on quarry detritus of open-cast oil-shale mining. Forest Ecology and Management 171(1-2), 191-198. https://doi.org/10.1016/ S0378-1127(02)00472-3

Schoeneberger, P.J., Wysocki, D.A., Benham, E.C. (Eds.)., 2012. Field book for describing and sampling soils. Version 3.0 (Natural Resources
Conservation Service, National Soil Survey Center, Lincoln, Nebraska, USA.

Scotti, R., Bonanomi, G., Scelza, R., Zoina, A., Rao, M.A., 2015. Organic amendments as sustainable tool to recovery fertility in intensive agricultural systems. Journal of Soil Science and Plant Nutrition 15(2), 333-352. http://dx.doi.org/10.4067/S0718-95162015005000031

Siebielec, G. et al., 2017. Raport z III etapu realizacji zamówienia „Monitoring Chemizmu soil Ornych w Polsce w Latach 2015-2017”. Instytut Uprawy, Nawożenia i Gleboznawstwa - Państwowy Instytut Badawczy, Puławy.

Soares, M.R., Alleoni, L.R., Vidal-Torrado, P., Cooper, M., 2005. Mineralogy and ion exchange properties of the particle size fractions of some Brazilian soils in tropical humid areas. Geoderma 125(3-4), 355-367. https://doi.org/10.1016/j.geoderma.2004.09.008

Stevenson, F.J., 1994. Humus chemistry: genesis, composition, reactions, 2nd ed., Wiley \& Sons, New York.

Vindušková, O., Frouz, J., 2013. Soil carbon accumulation after opencast coal and oil shale mining in Northern Hemisphere: a quantitative review. Environmental Earth Sciences 69(5), 1685-1698. https://doi-1org-10013e3hk0112.han.up.poznan.pl/10.1007/s12665012-2004-5

Widera, M., Kasztelewicz, Z., Ptak, M., 2016. Lignite mining and electricity generation in Poland: The current state and future prospects. Energy Policy 92, 151-157. https://doi.org/10.1016/j.enpol.2016.02.002

Zhang, G.J., Bai, Z.K., Wang, J.M., 2014. Preliminary study on cognition and utilization of minesoils. China Mining Magazine 3, 53-56.

Zhao, Z., Shahrour, I., Bai, Z., Fan, W., Feng, L., Li, H., 2013. Soils development in opencast coal mine spoils reclaimed for 1-13 years in the West-Northern Loess Plateau of China. European Journal of Soil Biology 55, 40-46. https://doi.org/10.1016/j.ejsobi.2012.08.006

Zoubková, L., Roubíková, I., Šefl, J., Rybářová, I., Banýr, P., 2015. Temperature and water potential of grey clays in relation to their physical, chemical and microbiological characteristics and phytocoenology within the scope of the Radovesice Dump. Eurasian Journal of Soil Science 4(3), 203-210. https://doi.org/http://dx.doi.org/10.18393/ejss. 2015.3.203-210

\section{Słowa kluczowe}

Tereny pogórnicze węgla brunatnego Rekultywacja rolnicza Medicago sativa L. Właściwości chemiczne gleb Węgiel organiczny

\section{Właściwości chemiczne Technosoli na terenach pogórniczych Konińsko-Tureckiego Zagłębia Węgla Brunatnego}

\section{Streszczenie}

Węgiel brunatny jest w dalszym ciągu jednym z głównych źródeł energii w wielu krajach. Jego eksploatacja metodą odkrywkową powoduje szereg zmian w środowisku przyrodniczym. Powstają nowe i trwałe formy reliefu: zwałowiska zewnętrzne i wewnętrzne zbudowane z mieszaniny skał znajdujących się w nadkładzie eksploatowanego węgla. Ten swoisty materiał macierzysty, w procesie rekultywacji, przekształcany jest w glebę. Celem pracy była ocena właściwości chemicznych gleb rozwijających się na terenach pogórniczych węgla brunatnego w Wielkopolsce. W ramach przeprowadzonych badań przeanalizowano wpływ lucerny (Medicago sativa L.) z trawą (Dactylis glomerata L.) na kształtowanie właściwości chemicznych gleb w 3 wariantach nawożenia mineralnego (0NPK - kontrola, 1NPK i 2NPK). W wyniku przeprowadzonych badań stwierdzono, że analizowane gleby dziedziczą po materiale macierzystym zasadowy odczyn, zawartość węglanów wapnia, zawartość przyswajalnego magnezu oraz CEC. Stwierdzono istotny wpływ Medicago sativa L., jak i nawożenia mineralnego na kształtowanie właściwości chemicznych badanych gleb. Uprawa Medicago sativa L. (na kombinacji 0NPK) spowodowało istotny statystycznie wzrost SOC, TN, oraz CEC w powierzchniowych poziomach Ap. Nawożenie mineralne dodatkowo zwiększało proces akumulacji SOC, TN, $\mathrm{P}_{2} \mathrm{O}_{5}, \mathrm{~K}_{2} \mathrm{O}$ oraz wzrost wartości CEC. Należy podkreślić, że niezależnie od poziomu nawożenia badane gleby były zasobniejsze w SOC, TN, CEC i przyswajalny Mg w porównaniu do średnich wartości liczbowych tych parametrów stwierdzonych w mineralnych glebach uprawnych w Polsce. 